\title{
Effect of Tillage and Nitrogen Rate on Corn Yield and Nitrogen and Phosphorus Uptake in a Corn-Soybean Rotation
}

\author{
Mahdi Al-Kaisi* and David Kwaw-Mensah
}

\begin{abstract}
Understanding tillage, $\mathbf{N}$, and $\mathbf{P}$ interactions can contribute to improved $N$ and $P$ utilization and crop response. This study examined the interaction effects of tillage and $N$ rate of two $N$ sources on $N$ and $P$ uptake by corn (Zea mays L.). The study was conducted on Kenyon loam (fine loamy, mixed, mesic Typic Hapludolls) soil at the Iowa State University Northeast Research and Demonstration Farm near Nashua, IA. A randomized complete block design with a split-plot arrangement in three replications was used for the two separate $\mathbf{N}$ source experiments. The tillage systems consist of no-tillage (NT), strip-tillage (ST), and chisel plow (CP) as main plots. Within each tillage four $\mathrm{N}$ rates $\left(0,85,170\right.$, and $\left.250 \mathrm{~kg} \mathrm{~N} \mathrm{ha}^{-1}\right)$ were assigned as subplots for each $\mathbf{N}$ source of manure (total $\mathbf{N}$ ) and fertilizer (anhydrous ammonia) in a corn-soybean [Glycine max (L.) Merr.] rotation. Tillage and increase in $\mathrm{N}$ rate beyond $85 \mathrm{~kg} \mathrm{ha}^{-1}$ had no effect on corn grain yield with both $N$ sources. Tillage $\times N$ rate had a significant effect on plant $N$ and $P$ uptake, especially at early growth stages with both $\mathbf{N}$ sources. Recovery percentage of applied $\mathbf{N}$ across all tillage systems and $N$ rates was $40 \%$ and $27 \%$ for manure and fertilizer sources, respectively, at the 12th-leaf growth stage of corn (V12). Plant $N$ and $P$ uptake at V12 growth stage was $44 \%$ and $37 \%$, respectively, across tillage systems, $N$ sources, and $N$ rates. The findings indicate that the $\mathrm{N}$ rate and seasonal variability have more influence on plant $N$ and $P$ uptake than does the tillage system.
\end{abstract}

$\mathrm{S}_{\mathrm{b}}$ OIL TILlage AND FERTILITY MANAGEMENT influence both nutrient and soil moisture dynamics in the soilplant system, which in turn affect nutrient use efficiency in a cropping system. Some of the tillage functions are to incorporate fertilizer and crop residues in the soil, improve soil aeration, and subsequently promote organic $\mathrm{N}$ and $\mathrm{P}$ mineralization (Carter and Rennie, 1987; Dinnes et al., 2002; Groffman et al., 1987; House et al., 1984; Huntington et al., 1985; McCarthy et al., 1995; Rice et al., 1987; Varco et al., 1993; Yoong et al., 2001). The tillage system can influence soil $\mathrm{N}$ availability due to its impact on soil organic $\mathrm{C}$ and $\mathrm{N}$ mineralization and subsequent plant $\mathrm{N}$ use or accumulation (Dinnes et al., 2002; Al-Kaisi and Licht, 2004; Licht and Al-Kaisi, 2005a; Gilliam and Hoyt, 1987; Mehdi et al., 1999; Sanju and Singh, 2001). Compared with NT, the conventional tillage (CT) system can significantly change the mineralizable $\mathrm{C}$ and $\mathrm{N}$ pools (Woods and Schuman, 1988). However, a long-term NT system has potentially greater mineralizable $\mathrm{C}$ and $\mathrm{N}$ pools compared with $\mathrm{CT}$ (Doran, 1980).

The plant $\mathrm{N}$ use can be altered by the different management practices and interactions between tillage sys-

Dep. of Agronomy, Iowa State Univ., Ames, IA 50011-1010. Received 6 Jan. 2007.*Corresponding author (malkaisi@iastate.edu).

Published in Agron. J. 99:1548-1558 (2007).

Tillage

doi:10.2134/agronj2007.0012

(c) American Society of Agronomy

677 S. Segoe Rd., Madison, WI 53711 USA tem, $\mathrm{N}$ rate, and $\mathrm{N}$ application timing. The interactive effects of different tillage systems, such as, NT, CT, or minimum tillage and $\mathrm{N}$ rate on grain $\mathrm{N}$ uptake was significant in increasing $\mathrm{N}$ removal with increasing $\mathrm{N}$ rate (Halvorson et al., 2001). Similarly, corn response to other management practices, such as the use of starter fertilizer with CT and ST systems, showed that corn silage and grain yields in CT systems were lower than those in ST; however, both silage and grain yields of both tillage systems increased with additional $\mathrm{N}$ applications (Mullins et al., 1998). An understanding of tillage and $\mathrm{N}$ source effect on the dynamics of $\mathrm{N}$ availability in soil and plant $\mathrm{N}$ uptake through the growing season at different growth stages is essential for determining the efficiency of $\mathrm{N}$ management. As the $\mathrm{N}$ availability is affected by the tillage system, $\mathrm{P}$ availability can equally be affected, leading to a P deficiency in many cropping systems. Many soils have large reserves of total P, but low levels of available P (Ortiz-Monasterio et al., 2002). On soils testing low in available $\mathrm{P}$, application of $\mathrm{P}$ fertilizer or liquid manure can increase crop yields, especially for corn and soybean (deMooy et al., 1973; Mallarino et al., 1991; Obreza and Rhoads, 1988; Webb et al., 1992). However, plant $P$ uptake varies with soil $P$ and moisture availability, and the concentration of $\mathrm{P}$ in plant tissue decreases with plant age and water stress (Payne et al., 1995). It was found that banded P (deep or shallow) increased early corn growth and $\mathrm{P}$ uptake compared with broadcast placement with NT (Mallarino et al., 1999). Liquid manure can be a valuable source for plant $\mathrm{P}$ nutrient need. In a study comparing liquid swine manure with chemical $\mathrm{N}$ and $\mathrm{P}$ fertilizer sources, it was found that corn yield and $\mathrm{N}$ and $\mathrm{P}$ uptake was similar for both $\mathrm{N}$ sources (Al-Kaisi and Waskom, 2002).

The value of liquid manure as a nutrient source to plant growth and the proximity of such source to field crop production can help reduce the cost of corn production as producing and transporting chemical fertilizers is costly. Therefore, this research explored this alternative source for $\mathrm{N}$ and $\mathrm{P}$. Information on tillage and $\mathrm{N}$ source effects on $\mathrm{N}$ and $\mathrm{P}$ use efficiency in corn is limited. Our objective was to examine the interactive effects of three tillage systems (NT, ST, and CP) and four $\mathrm{N}$ rates of liquid swine manure and $\mathrm{N}$ fertilizer on corn response and $\mathrm{N}$ and $\mathrm{P}$ use efficiencies.

\section{MATERIALS AND METHODS Site Description}

This study was conducted on a 16-ha site at the Iowa State University Northeast Research and Demonstration farm near

Abbreviations: CP, chisel plow; CT, conventional tillage; NT, no-tillage; R6, physiological maturity stage of corn; ST, strip-tillage; V6, sixth-leaf stage of corn; V12, 12th-leaf stage of corn; VT, tassel stage of corn. 
Nashua, IA $\left(43^{\circ} 0^{\prime} \mathrm{N}, 92^{\circ} 30^{\prime} \mathrm{W}\right)$ from 2002 to 2004 . The previous tillage system on this site was $\mathrm{CP}$ as primary tillage with field cultivation as a secondary tillage before implementing the three tillage treatments of NT, ST, and CP in year 2000. The 16-ha site was divided into two 8-ha areas (east and west sites) for corn and soybean rotations. The soil at the site is a nearly level to gently sloping Kenyon loam (fine loamy, mixed, mesic Typic Hapludolls). The average annual precipitation in northeastern Iowa is $896 \mathrm{~mm}$ with a growing season rainfall average of $701 \mathrm{~mm}$. Initial values of total soil P (Bray and Kurtz, 1945), $\mathrm{K}$ (Thomas, 1982), $\mathrm{NO}_{3}-\mathrm{N}$ (Mulvaney, 1996), organic matter by dry combustion using a LECO CHN-2000 analyzer, and $\mathrm{pH}$ (McLean, 1982) in the top $15 \mathrm{~cm}$ were 35, 163, and $11 \mathrm{mg} \mathrm{kg}^{-1}$, $580 \mathrm{~g} \mathrm{~kg}^{-1}$, and 6.4 , respectively.

This study focused on corn response in a corn-soybean rotation. During the corn year, the 8-ha site was split into two 4-ha sites (north and south sites) for applying two sources of $\mathrm{N}$. At one site (4 ha), corn received liquid swine manure, which will be referred to as manure at four different $\mathrm{N}$ rates based on total $\mathrm{N}\left(0,85,170\right.$, and $\left.250 \mathrm{~kg} \mathrm{~N} \mathrm{ha}^{-1}\right)$, while on the adjacent 4-ha site, chemical fertilizer (anhydrous ammonia) was applied at the same $\mathrm{N}$ rates, which will be referred to as fertilizer.

The experimental design for each corn-N source and tillage experiment was a randomized complete block with split-plots arranged in three replications. Three tillage systems of NT, ST, and $\mathrm{CP}$ were randomly assigned to each replication as the main plot treatments, and the four $\mathrm{N}$ rates were assigned randomly to each tillage treatment as subplot treatments during each corn year. Each tillage plot was approximately $56 \mathrm{~m}$ long by $21 \mathrm{~m}$ wide, with subplots of each $\mathrm{N}$ rate within main tillage plots being $56 \mathrm{~m}$ long by $5 \mathrm{~m}$ wide. Each tillage treatment stayed on the same plot for the duration of the study.

In 2002, the eastern half of the experimental site was planted to corn and the western half planted to soybean. In 2003 and 2004, corn and soybean crops were planted in the order of soybean following corn on these two sites to establish the corn-soybean rotation. The soybeans were planted in a $76-\mathrm{cm}$ row spacing at a seeding rate of 420,000 plants ha ${ }^{-1}$ using the same tillage treatments as in corn every year.

After harvest in mid-November of each year, CP and ST treatments were performed to both corn and soybean plots. A straight-disc coulter was used in front of the chisel points to cut through residue. Strip-tillage was performed with a six-row ST unit equipped with mole knives attached to a toolbar and centered between two 46-cm-diameter closing disks. These attachments created a 20 -cm-deep tilled zone with 8 -cm berms.

Each year before field application of manure, three representative liquid swine manure samples were collected in a plastic container from the manure applicator. The manure samples were mixed well and then $500-\mathrm{mL}$ subsamples were collected in plastic bottles and placed in a cooler with ice for transfer to the laboratory for the same-day analysis, or were stored in a $-4^{\circ} \mathrm{C}$ freezer. During each year, the three manure samples were analyzed individually for total $\mathrm{C}$, total $\mathrm{N}$, total $\mathrm{P}$, total $\mathrm{K}$, ammonium nitrogen $\left(\mathrm{NH}_{4}-\mathrm{N}\right)$, and nitrate nitrogen $\left(\mathrm{NO}_{3}-\mathrm{N}\right)$ concentrations using the macro Kjeldahl (Kane, 1999), AOAC-965.17 photometric method (AOAC, 1997), the EPA-7610 atomic absorption method (EPA, 1986), and the EPA-353.3 automated cadmium reduction method (EPA, 1974), respectively. Three-year averages of manure analysis were: total C, $47 \mathrm{~g} \mathrm{~kg}^{-1}$; total $\mathrm{N}, 6.8 \mathrm{~g} \mathrm{~L}^{-1}$; total $\mathrm{P}, 4.9 \mathrm{~g} \mathrm{~L}^{-1}$; total $\mathrm{K}$, $4.6 \mathrm{~g} \mathrm{~L}^{-1} ; \mathrm{NH}_{4}-\mathrm{N}, 5.0 \mathrm{~g} \mathrm{~L}^{-1}$; and $\mathrm{NO}_{3}-\mathrm{N}, 4.5 \mathrm{mg} \mathrm{L}^{-1}$. Each manure application rate was based on the average of the three samples of total $\mathrm{N}$ concentration. Each year, manure was injected 10 to $15 \mathrm{~cm}$ below the soil surface on 15, 23, and 27 Nov. 2002,2003 , and 2004, respectively, at the rates of $0,85,170$, and
$250 \mathrm{~kg} \mathrm{~N} \mathrm{ha}^{-1}$ in each corn year using a Badger $5800 \mathrm{~L}$ manure applicator (Badger Northland, Inc., Kaukauna, WI) equipped with a modified injection knife to cause minimum soil disturbance in the same direction and location of previous rows in all tillage systems. No manure was applied after corn harvest or during the soybean season.

Anhydrous ammonia was knifed in early April of each year using a six-row, pull-type anhydrous ammonia injection knife applicator. The anhydrous ammonia was injected 10 to $15 \mathrm{~cm}$ deep with modified injection knives to cause minimum soil disturbance. Corn was planted on the manure and anhydrous ammonia bands in all tillage systems. During planting in May of each year, starter fertilizer was applied to the anhydrous ammonia plots by applying $29 \mathrm{~kg} \mathrm{P} \mathrm{ha}^{-1}$ as $\mathrm{NH}_{4} \mathrm{H}_{2} \mathrm{PO}_{4}$ and $35 \mathrm{~kg} \mathrm{~K}^{-1}$ as $\mathrm{KCl}$, placed $5 \mathrm{~cm}$ deep and $5 \mathrm{~cm}$ from the row center.

The CP system plots were field cultivated in the spring before planting corn to control weeds and level the soil surface. In all tillage systems, corn was planted in early May of each year using DeKalb 537 non-Bacillus thuringiensis corn at a seeding rate of 84,000 plants $\mathrm{ha}^{-1}$ and $76-\mathrm{cm}$ row spacing. Corn was planted over the disturbed application zone of manure and anhydrous ammonia of all tillage systems. During planting, the area was simultaneously sprayed with $189 \mathrm{~mL} \mathrm{ha}^{-1}$ acetochlor [2-chloro- $N$-(ethoxymethyl)- $N$-(2-ethyl-6-methylphenyl) acetamide]. Corn was harvested using a combine with a scale yield monitor. Harvested corn grain was adjusted to $150 \mathrm{~g} \mathrm{~kg}^{-1}$ moisture to estimate final yield.

\section{Crop Measurements}

Plant samples of corn were collected at the sixth-leaf (V6), 12th-leaf (V12), tassel (VT), and physiological maturity (R6) growth stages for each split-plot to estimate dry matter production (Ritchie et al., 1993; Al-Kaisi and Yin, 2003). The sampling area per split-plot was $4.6 \mathrm{~m}$ long, which was divided into three $1.53-\mathrm{m}$ segments. A separate area was maintained for yield harvest. At each of the four growth stages, one plant per $1.53-\mathrm{m}$ segment of the sampling area was cut at ground level having two plants on both sides of the harvested plant. A total of three plants were cut at ground level from the 4.6-m-long row at each growth stage. Plant samples were oven-dried at $60^{\circ} \mathrm{C}$ for $8 \mathrm{~d}$ to achieve a constant dry mass. Oven-dried plant samples were ground using a Wiley Mill Model 2 carbon steel pulverizer (Arthur H. Thomas Co., Philadelphia, PA). Ground samples were placed in plastic-lined paper bags before analysis. Concentrations of total $\mathrm{N}$ and total $\mathrm{P}$ were determined by dry combustion using a LECO CHN-2000 C-N analyzer and the microwave digestion and inductively coupled plasma (ICP) method, respectively. Plant and corn grain $\mathrm{N}$ and $\mathrm{P}$ uptake were estimated as products of total plant dry matter or grain yield and their respective total $\mathrm{N}$ and total $\mathrm{P}$ concentrations.

The recovery percentages of applied $\mathrm{N}$ and $\mathrm{P}$ by grain and corn plant at different growth stages were calculated by using the following relationship:

$$
\begin{aligned}
& \mathrm{N} \text { or } \mathrm{P} \text { recovery } \%=[(\mathrm{N} \text { or } \mathrm{P} \text { treatment uptake } \\
& \quad-\text { control uptake }) /(\mathrm{N} \text { or } \mathrm{P}) \text { of applied } \mathrm{N} \text { or } \mathrm{P} \text { rate }] \\
& \quad \times 100
\end{aligned}
$$

The 3-yr averages of applied $\mathrm{P}$ corresponding to the $\mathrm{N}$ rates of $0,85,170$, and $250 \mathrm{~kg} \mathrm{~N}^{-1}$ of manure were $0,56,113$, and $178 \mathrm{~kg} \mathrm{P} \mathrm{ha}^{-1}$, respectively. These values were used in calculating total $\mathrm{P}$ recovery from manure. For the fertilizer experiment, the applied rate of $29 \mathrm{~kg} \mathrm{P}^{-1}$ was used in calculating the total $\mathrm{P}$ recovery. 


\section{Late Spring Soil $\mathrm{NO}_{3}-\mathrm{N}$ Concentration}

Late spring $\mathrm{NO}_{3}-\mathrm{N}$ test is a $\mathrm{N}$ management tool used to manage $\mathrm{N}$ application more efficiently. Soil samples were collected at the V6 growth stage for all treatments to measure late spring soil $\mathrm{NO}_{3}-\mathrm{N}$ concentration. A $30-\mathrm{cm}-$ long soil probe with a hardened cutting tip with an inside diameter of $1.9 \mathrm{~cm}$ was used for soil sampling. Soil samples were collected from a 4.6-m-long row in the center of each plot. This area was divided into three 1.53 -m-long sections. Soil sampling was conducted at two depths, from 0 to 30 and from 30 to $60 \mathrm{~cm}$ during the time of plant sampling. Ten to 12 soil cores were collected for each soil depth from each $1.53-\mathrm{m}$ section of the sampling area within and between rows of each plot and kept in plasticlined paper bags and frozen. The soil samples from each $1.53-\mathrm{m}$ section were air-dried and analyzed separately for $\mathrm{NO}_{3}-\mathrm{N}$ concentration using the $\mathrm{KCl}$ extraction method (Mulvaney, 1996). The average of the soil $\mathrm{NO}_{3}-\mathrm{N}$ concentration of the three soil sample sections for each plot was used in data analysis.

\section{Fall Stalk $\mathrm{NO}_{3}-\mathrm{N}$ Concentration}

The fall stalk $\mathrm{NO}_{3}-\mathrm{N}$ test was used to evaluate the efficient utilization of $\mathrm{N}$ by corn. Nitrate- $\mathrm{N}$ concentration in the corn stalk was evaluated according to criteria that were established to evaluate a $\mathrm{N}$ fertilization program for the following season (Blackmer and Mallarino, 1996). Fall corn stalk $\mathrm{NO}_{3}-\mathrm{N}$ concentration was determined by collecting corn stalk samples from all treatments after corn reached R6 growth stage, when at least $80 \%$ of the kernels of most ears had black layer (physiological maturity) (Blackmer and Mallarino, 1996). A 20-cm-long segment of each corn stalk was taken 15 to $35 \mathrm{~cm}$ above ground level, and leaf sheaths were removed from samples. A total of 15 corn stalks were collected from each treatment and placed in a paper bag for drying. Corn stalk samples were oven-dried at $60^{\circ} \mathrm{C}$ for $8 \mathrm{~d}$ to attain a constant dry mass before grinding with the carbon steel pulverizer. The ground corn stalks were sealed in plastic-lined paper bags for storage before analysis. Samples were analyzed for corn stalk $\mathrm{NO}_{3}-\mathrm{N}$ concentrations using the $2 \mathrm{M}$ potassium chloride (KCl) extraction method (Mulvaney, 1996) using a Lachat QuickChem FAI+8000 series with cadmium reduction column. Corn stalk nitrate concentrations were expressed as $\mathrm{mg}$ $\mathrm{NO}_{3}-\mathrm{N} \mathrm{kg}^{-1}$ of dry corn stalk.

\section{Statistical Analysis}

Statistical analysis of the data was performed using a statistical analysis system package (SAS Institute, 2003). Data from each $\mathrm{N}$-source experiment were analyzed separately for the main and interaction effects between year, tillage, and $\mathrm{N}$ rate by using the GLM procedure for analysis of variance appropriate for a randomized complete block design with a split-plot arrangement. Mean separations were performed by using the least significant difference $(P \leq 0.05)$. The interaction effects of treatments were presented for both $\mathrm{N}$ sources.

\section{RESULTS AND DISCUSSION}

\section{Grain Yield Response to Tillage and N Rate}

The main effect of tillage on grain yield was not significant with all $\mathrm{N}$ rates of both $\mathrm{N}$ sources (Table 1). Regardless of tillage system or $\mathrm{N}$ source, increasing the $\mathrm{N}$ rate above $85 \mathrm{~kg} \mathrm{~N} \mathrm{ha}^{-1}$ had no significant effect in increasing grain yield. This is in agreement with $\mathrm{N}$ recom-
Table 1. Effect of tillage systems and $\mathbf{N}$ rates of two $\mathbf{N}$ sources on corn grain yield in 2002-2004.

\begin{tabular}{|c|c|c|c|c|c|}
\hline \multirow[b]{2}{*}{ N source } & \multirow[b]{2}{*}{ Tillage system $\dagger$} & \multicolumn{4}{|c|}{$\mathrm{N}$ rate, $\mathrm{kg} \mathrm{ha}^{-1}$} \\
\hline & & $\mathbf{0}$ & 85 & 170 & 250 \\
\hline & & & grain yiel & $\mathrm{Mg} \mathrm{ha}^{-}$ & \\
\hline \multirow[t]{3}{*}{ Manure } & NT & $6.7 \mathrm{Ab} \div$ & $9.3 \mathrm{Aa}$ & 10.5Aa & 10.7Aa \\
\hline & ST & 7.0Ab & 9.7Aa & $10.4 \mathrm{Aa}$ & 10.8Aa \\
\hline & $\mathbf{C P}$ & 8.0Ab & 10.7Aa & 11.0Aa & 11.3Aa \\
\hline \multirow[t]{3}{*}{ Fertilizer } & NT & $6.5 \mathrm{Ab}$ & 10.1Aa & $10.6 \mathrm{Aa}$ & 10.5Aa \\
\hline & ST & 8.6Ab & 10.1Aa & $10.3 \mathrm{Aa}$ & 10.3Aa \\
\hline & $\mathbf{C P}$ & 7.9Ab & 10.0Aa & $10.5 \mathrm{Aa}$ & $10.6 \mathrm{Aa}$ \\
\hline
\end{tabular}

$\dagger$ NT, no-tillage; ST, strip-tillage; CP, chisel plow.

$\downarrow$ Means in columns within each $\mathbf{N}$ rate with the same uppercase letter are not significantly different according to least-square means for tillage and $\mathrm{N}$ rate interactions adjusted for multiple comparisons at $P \leq 0.05$. Means in rows within each tillage system with the same lowercase letter are not significantly different according to least-square means for tillage and $\mathbf{N}$ rate interactions adjusted for multiple comparisons at $\boldsymbol{P} \leq \mathbf{0 . 0 5}$.

mendations for corn after soybean in Iowa, where it ranges from 100 to $145 \mathrm{~kg} \mathrm{ha}^{-1}$ (Blackmer et al., 1997). Also, these findings are in agreement with those by Licht and Al-Kaisi (2005a) for the same tillage systems. Generally, all tillage systems showed lower grain yields with zero $\mathrm{N}$ rate compared with high $\mathrm{N}$ rates regardless of $\mathrm{N}$ source. The corn response to different tillage systems and $\mathrm{N}$ management showed that type of tillage system has little effect on corn yield despite the initial differences in corn germination due to increases in soil temperature of 1.2 to $1.4^{\circ} \mathrm{C}$ for ST and CP over NT in the top $5 \mathrm{~cm}$ (Licht and Al-Kaisi, 2005b). It was reported by others that the poor early season vegetative growth in the NT was due to low $\mathrm{N}$ availability (increased N immobilization, denitrification, and reduced organic $\mathrm{N}$ mineralization) and reduction in nutrient uptake by plants, which subsequently reduced crop yield compared with the ST and CP systems (Griffith et al., 1977; Ketchenson, 1980; Karlen et al., 1991; Mallarino et al., 1999). Regardless of tillage system, corn grain yield response depicted $\mathrm{N}$ poverty adjustment, where grain yield increased with additional $85 \mathrm{~kg} \mathrm{~N} \mathrm{ha}^{-1}$ with no significant increase in yield above that $\mathrm{N}$ rate (Macy, 1936; Cerrato and Blackmer, 1990; Al-Kaisi and Waskom, 2002).

\section{Tillage and $\mathbf{N}$ Rate Effects on Grain $\mathbf{N}$ and P Uptake}

Grain $\mathrm{N}$ and $\mathrm{P}$ uptake showed no significant differences between tillage systems for all $\mathrm{N}$ rates with manure (Table 2). In the manure source plots, regardless of tillage system, the grain $\mathrm{N}$ and $\mathrm{P}$ uptake had significantly increased with additional $\mathrm{N}$ application and the greatest $\mathrm{N}$ and $\mathrm{P}$ uptake was achieved with $250 \mathrm{~kg} \mathrm{~N}^{-1}$ of manure. The control treatment had the lowest grain $\mathrm{N}$ uptake (Table 2). The increase in $\mathrm{N}$ and $\mathrm{P}$ accumulation in grain can be attributed to greater yield response and $\mathrm{N}$ and $\mathrm{P}$ availability at the high manure application rate. The results showed that even with the increase of $\mathrm{N}$ application rate, which led to an increase in $\mathrm{P}$ application with manure source (manure application rate based on total $\mathrm{N}$ content), the increase in applied $\mathrm{P}$ had no effect on increasing grain $\mathrm{P}$ uptake or accumulation in the grain. 
Table 2. Grain $N$ and $P$ uptake with different tillage systems and $N$ rates of manure and fertilizer in 2002-2004.

\begin{tabular}{|c|c|c|c|c|c|c|c|c|c|}
\hline \multirow[b]{2}{*}{ N source } & \multirow[b]{2}{*}{ Tillage system $\dagger$} & \multicolumn{4}{|c|}{$\mathrm{N}$ rate, $\mathrm{kg} \mathrm{ha}^{-1}$} & \multicolumn{4}{|c|}{$\mathrm{N}$ rate, $\mathrm{kg} \mathrm{ha}^{-1}$} \\
\hline & & $\mathbf{0}$ & 85 & 170 & 250 & $\mathbf{0}$ & 85 & 170 & 250 \\
\hline & & - & - total $\mathbf{N} u$ & , $\operatorname{kg~ha}^{-1}$ & & & - total P u & e, $\mathrm{kg} \mathrm{ha}^{-1}$ & \\
\hline \multirow[t]{3}{*}{ Manure } & NT & 79.7Ad $\$$ & 101.8Ac & 122.1Ab & 137.3Aa & 11.7Ac & 17.0Ab & 17.1Ab & 21.5Aa \\
\hline & ST & 82.5Ac & 112.3Ab & 126.0Aa & 134.4Aa & 13.1Ab & 18.7Aa & 17.0Aab & 19.9Aа \\
\hline & $\mathbf{C P}$ & 82.7Ac & 113.8Ab & $115.6 \mathrm{Ab}$ & 143.4Aa & 11.6Ab & 19.7Aa & 17.9Aa & 19.7Aa \\
\hline \multirow[t]{3}{*}{ Fertilizer } & NT & $76.6 \mathrm{Bc}$ & 122.4Bb & 144.5Aa & 142.5Aa & $10.2 \mathrm{Ab}$ & 16.3Aa & $16.6 \mathrm{Aa}$ & 16.6Aa \\
\hline & ST & 99.4Ab & 135.0Aa & 130.5Ba & 139.1Aa & 11.0Ab & 14.1Aab & 16.0Aa & 14.7Aab \\
\hline & $\mathbf{C P}$ & 86.9ABb & 116.6Ba & 126.0Ba & 131.1Aa & $12.0 \mathrm{Ab}$ & 16.7Aa & 15.5Aab & 15.9Aab \\
\hline
\end{tabular}

$\dagger$ NT, no-tillage; ST, strip-tillage; CP, chisel plow.

$\$$ Means in columns within each $\mathbf{N}$ rate with the same uppercase letter are not significantly different according to least square means for tillage and $\mathbf{N}$ rate interactions adjusted for multiple comparisons at $\boldsymbol{P} \leq \mathbf{0 . 0 5}$. Means in rows within each tillage system with the same lowercase letter are not significantly different according least square means for tillage and $\mathrm{N}$ rate interactions adjusted for multiple comparisons at $\boldsymbol{P} \leq \mathbf{0 . 0 5}$.

In the fertilizer source plots, ST grain $\mathrm{N}$ uptake was greater compared with NT and CP, especially at 0 and $85 \mathrm{~kg} \mathrm{~N} \mathrm{ha}^{-1}$ (Table 2). However, grain $\mathrm{P}$ uptake with different tillage systems was not significantly different regardless of $\mathrm{N}$ rate. The only difference in $\mathrm{P}$ uptake with fertilizer source was observed between zero and other $\mathrm{N}$ rates across all tillage systems. The greater grain $\mathrm{N}$ uptake with the fertilizer source in ST compared with the NT can be attributed to better soil conditions associated with the ST system, where early spring increase in soil temperature in poorly drained soils improved corn germination, compared with NT as documented by Licht and Al-Kaisi (2005b).

\section{Tillage and N Rate Effects on Grain Recovery of Applied $\mathbf{N}$ and $\mathbf{P}$}

The grain recovery of applied $\mathrm{N}$ from both $\mathrm{N}$ sources was generally greater with the $85 \mathrm{~kg} \mathrm{~N} \mathrm{ha}^{-1}$ rate compared with the other two higher application $\mathrm{N}$ rates in all tillage systems (Table 3). However, it was observed that both ST and CP improved grain $\mathrm{N}$ recovery, especially with manure source at the $85 \mathrm{~kg} \mathrm{~N} \mathrm{ha}^{-1}$ rate. The increase in $\mathrm{N}$ application rate beyond $85 \mathrm{~kg} \mathrm{~N}^{-1}$ did not increase grain $\mathrm{N}$ recovery with all tillage systems. It was observed that grain $\mathrm{N}$ recovery of applied $\mathrm{N}$ fertilizer with NT was greater compared with ST and $\mathrm{CP}$ at 85 and $170 \mathrm{~kg} \mathrm{~N} \mathrm{ha}{ }^{-1}$ rates. These finding are consistent with those by Al-Kaisi and Waskom, 2002. It appears that the increase in $\mathrm{N}$ rate beyond $85 \mathrm{~kg} \mathrm{~N}^{-1}$ did not contribute significantly to recovering applied $\mathrm{N}$ with both $\mathrm{N}$ sources regardless of tillage system. The grain $\mathrm{P}$ recov- ery was significantly greater with $\mathrm{CP}$ treatment compared with the NT or ST with manure at $85 \mathrm{~kg} \mathrm{~N}^{-1}$ rate. The increased amount of applied $\mathrm{P}$ with manure did not lead to greater grain $\mathrm{P}$ recovery, where manure $\mathrm{N}$ rate application was based on total $\mathrm{N}$ content.

However, NT grain P recovery in the fertilizer source plots was significantly greater than that with ST or CP at all $\mathrm{N}$ rates (Table 3). These findings are in agreement with those described by Al-Kaisi and Licht (2004) for the same tillage systems.

\section{Effects of Tillage, $\mathbf{N}$ Rate, and Season Interactions on Grain $\mathbf{N}$ and $P$ Uptake and Recovery}

Interaction effects of tillage $\times \mathrm{N}$ rate, tillage $\times$ year, and $\mathrm{N}$ rate $\times$ year on grain $\mathrm{N}$ and $\mathrm{P}$ uptake were frequently observed with both $\mathrm{N}$ sources, although inconsistent (Table 4). The only significant interaction between tillage and $\mathrm{N}$ rate was observed with grain $\mathrm{N}$ uptake for the fertilizer source. The tillage $\times$ year interaction had a significant effect on grain $\mathrm{N}$ and $\mathrm{P}$ uptake of manure source and on grain $\mathrm{N}$ uptake with fertilizer source. However, the $\mathrm{N}$ rate $\times$ year interaction had a significant effect on grain $\mathrm{N}$ and $\mathrm{P}$ uptake with manure and fertilizer sources, respectively (Table 4). Even though these interactions are inconsistent with both $\mathrm{N}$ sources, they reflect the seasonal variability effect on grain $\mathrm{N}$ and $\mathrm{P}$ uptake with different tillage systems. Generally, there was an insignificant three-way interaction of tillage $\times \mathrm{N}$ rate $\times$ year effect on grain $\mathrm{N}$ and $\mathrm{P}$ uptake with both $\mathrm{N}$ sources. These finding are consistent with observations described by Dharmakeerthi et al. (2006), where $\mathrm{N}$ fer-

Table 3. Grain $N$ and $P$ recovery with various tillage systems and $N$ rates of manure and fertilizer in 2002-2004.

\begin{tabular}{|c|c|c|c|c|c|c|c|c|c|}
\hline \multirow[b]{2}{*}{ N source } & \multirow[b]{2}{*}{ Tillage system $\dagger$} & \multicolumn{8}{|c|}{$\mathrm{N}$ rate, $\mathrm{kg} \mathrm{ha}^{-1}$} \\
\hline & & 0 & 85 & 170 & 250 & 0 & 85 & 170 & 250 \\
\hline & & & -1 & ery, \% - & - & - & - & ery, \% & \\
\hline \multirow[t]{3}{*}{ Manure } & NT & - & 26.0Ba $\neq$ & 25.0Aa & 23.1Aa & - & $9.5 \mathrm{Ba}$ & $4.7 \mathrm{Ab}$ & $5.5 \mathrm{Ab}$ \\
\hline & ST & - & 35.1Aa & $25.6 \mathrm{Ab}$ & 20.8Ab & - & 9.9Ba & 3.4Ab & 3.8Ab \\
\hline & $\mathbf{C P}$ & - & $36.6 \mathrm{Aa}$ & $19.4 \mathrm{Ac}$ & 24.3Ab & - & 14.3Aa & $5.5 \mathrm{Ab}$ & $4.5 \mathrm{Ab}$ \\
\hline \multirow[t]{3}{*}{ Fertilizer } & NT & - & 53.9Aa & $40.0 \mathrm{Ab}$ & $26.4 \mathrm{Ac}$ & - & 21.4Aa & 22.2Aa & $22.4 \mathrm{Aa}$ \\
\hline & ST & - & $41.9 \mathrm{Ba}$ & $18.3 \mathrm{Bb}$ & 15.9Ab & - & 10.6Bb & $17.3 \mathrm{Aa}$ & 12.9Bab \\
\hline & CP & - & $34.9 \mathrm{Ba}$ & $23.0 \mathrm{Bb}$ & 17.7Ac & - & 16.1ABa & $11.8 \mathrm{Bb}$ & 13.3Bb \\
\hline
\end{tabular}

$\dagger$ NT, no-tillage; ST, strip-tillage; CP, chisel plow.

$\$$ Means in columns within each $\mathbf{N}$ rate with the same uppercase letter are not significantly different according to least square means for tillage and $\mathbf{N}$ rate interactions adjusted for multiple comparisons at $\boldsymbol{P} \leq \mathbf{0 . 0 5}$. Means in rows within each tillage system with the same lowercase letter are not significantly different according least square means for tillage and $N$ rate interactions adjusted for multiple comparisons at $P \leq 0.05$. 
Table 4. Interaction effects of tillage, $\mathbf{N}$ rate, and year on $\mathbf{N}$ and $P$ uptake by corn plant and grain with manure and fertilizer N sources.

\begin{tabular}{|c|c|c|c|c|c|}
\hline \multirow{3}{*}{$\begin{array}{l}\text { Growth } \\
\text { stage } \dagger\end{array}$} & \multirow[b]{3}{*}{ Source } & \multicolumn{4}{|c|}{$\boldsymbol{P}>\boldsymbol{F}$} \\
\hline & & \multicolumn{2}{|c|}{ Manure } & \multicolumn{2}{|c|}{ Fertilizer } \\
\hline & & N uptake & P uptake & N uptake & P uptake \\
\hline \multirow[t]{4}{*}{ V6 } & tillage $\times N$ rate & 0.001 & 0.034 & 0.005 & 0.001 \\
\hline & tillage $\times$ year & 0.008 & 0.074 & 0.019 & 0.002 \\
\hline & $N$ rate $\times$ year & $<0.0001$ & 0.006 & $<0.0001$ & $<\mathbf{0 . 0 0 0 1}$ \\
\hline & $\begin{array}{l}\text { tillage } \times \mathrm{N} \text { rate } \\
\times \text { year }\end{array}$ & 0.214 & 0.257 & 0.073 & 0.0468 \\
\hline \multirow[t]{4}{*}{ V12 } & tillage $\times N$ rate & 0.077 & 0.158 & 0.329 & 0.926 \\
\hline & tillage $\times$ year & 0.496 & 0.047 & 0.113 & 0.556 \\
\hline & $N$ rate $\times$ year & $<0.0001$ & 0.350 & 0.029 & 0.196 \\
\hline & $\begin{array}{l}\text { tillage } \times \mathbf{N} \text { rate } \\
\times \text { year }\end{array}$ & 0.365 & 0.264 & 0.280 & 0.175 \\
\hline \multirow[t]{4}{*}{ VT } & tillage $\times N$ rate & 0.887 & 0.293 & 0.016 & 0.973 \\
\hline & tillage $\times$ year & 0.559 & 0.004 & 0.216 & 0.741 \\
\hline & $\mathbf{N}$ rate $\times$ year & $<0.0001$ & 0.026 & 0.003 & 0.746 \\
\hline & $\begin{array}{l}\text { tillage } \times \mathbf{N} \text { rate } \\
\times \text { year }\end{array}$ & 0.332 & 0.530 & 0.576 & 0.985 \\
\hline \multirow[t]{4}{*}{ R6 } & tillage $\times N$ rate & $<0.0001$ & 0.001 & 0.535 & 0.015 \\
\hline & tillage $\times$ year & 0.950 & 0.043 & 0.973 & 0.320 \\
\hline & $N$ rate $\times$ year & 0.002 & 0.002 & 0.005 & 0.101 \\
\hline & $\begin{array}{l}\text { tillage } \times \mathbf{N} \text { rate } \\
\times \text { year }\end{array}$ & 0.225 & 0.020 & 0.098 & 0.002 \\
\hline \multirow[t]{4}{*}{ Grain } & tillage $\times N$ rate & 0.251 & 0.813 & 0.004 & 0.830 \\
\hline & tillage $\times$ year & $<0.0001$ & 0.049 & 0.006 & 0.715 \\
\hline & $\mathbf{N}$ rate $\times$ year & 0.110 & 0.008 & 0.021 & 0.927 \\
\hline & tillage $\times \mathbf{N}$ rate & 0.149 & 0.265 & 0.047 & 0.978 \\
\hline
\end{tabular}

$\dagger$ V6, sixth-leaf stage of corn; V12, 12th-leaf stage of corn; VT, tassel stage of corn; R6, physiological maturity stage of corn. Significant level $(P \leq 0.05)$.

tilizer level and tillage interaction effect was not significant during any growth stage.

The grain $\mathrm{N}$ and $\mathrm{P}$ recovery interactions are summarized in Table 5. Tillage $\times N$ rate, tillage $\times$ year, $N$ rate $\times$ year, and tillage $\times \mathrm{N}$ rate $\times$ year interactions had no significant effect on grain $\mathrm{N}$ and $\mathrm{P}$ recovery with both $\mathrm{N}$ sources, except in a few cases. It appears that tillage $X$ year had a significant effect on grain $\mathrm{P}$ and $\mathrm{N}$ and $\mathrm{P}$ recoveries with manure and fertilizer sources, respectively (Table 5). This can be attributed to tillage effect on both $\mathrm{N}$ and $\mathrm{P}$ availability and $\mathrm{N}$ and $\mathrm{P}$ uptake. It was found that banded P (deep or shallow) increased early corn growth and $\mathrm{P}$ uptake more than broadcast placement with NT (Mallarino et al., 1999).

\section{Tillage and $\mathbf{N}$ Rate Effects on Plant $\mathbf{N}$ and P Uptake at Different Growth Stages}

Generally, plant $\mathrm{N}$ uptake was significantly greater with the CP system compared with NT at 85 and $170 \mathrm{~kg}$ $\mathrm{N} \mathrm{ha}{ }^{-1}$ rates of manure source at V6 to $\mathrm{R} 6$ growth stages (Table 6). The observed tillage effect on the plant $\mathrm{N}$ uptake may be attributed to the differences in crop growth rates because $\mathrm{N}$ uptake is controlled by $\mathrm{N}$ availability and crop growth rate (Devienne-Barret et al., 2000). The plant $\mathrm{N}$ uptake at the $250 \mathrm{~kg} \mathrm{~N}^{-1} \mathrm{~N}$ rate was inconsistent during all growth stages. The differences in plant $\mathrm{N}$ uptake between $\mathrm{N}$ rates within each tillage system showed generally greater plant $\mathrm{N}$ uptake with the increase in $\mathrm{N}$ rate up to $170 \mathrm{~kg} \mathrm{~N} \mathrm{ha}{ }^{-1}$ for the manure source. These findings are in agreement with those by Dharmakeerthi et al. (2006), where plants growing in treatments with higher $\mathrm{N}$ application took up significantly more $\mathrm{N}$ than zero- $\mathrm{N}$ treatments at all growth stages.

The plant $\mathrm{P}$ uptake was generally not significantly different for all tillage systems at $0 \mathrm{~kg} \mathrm{~N} \mathrm{ha}^{-1}$ rate during all growth stages with manure source (Table 6). However, the increase in application of $\mathrm{N}$ rate showed inconsistent differences between tillage systems for plant $\mathrm{P}$ uptake with some advantages for CP and ST systems over NT. The increase in manure application rate that led to a greater amount of $\mathrm{P}$ application did not cause significant differences in plant $\mathrm{P}$ uptake between tillage treatments. These findings are not surprisingly unexpected due to high soil-P test of the site.

In the fertilizer source plots, the tillage effect on plant $\mathrm{N}$ uptake with different $\mathrm{N}$ rates was highly variable during all growth stages (Table 7). At the V6 to R6 growth stages, the difference in plant $\mathrm{N}$ uptake was only significant between zero and high $\mathrm{N}$ rates across all tillage systems. It was noticeable at the VT growth stage that a maximum $\mathrm{N}$ accumulation was reached and greater plant $\mathrm{N}$ uptake was observed at all fertilizer $\mathrm{N}$ rates for the $\mathrm{CP}$ tillage system, except at the $250 \mathrm{~kg} \mathrm{~N} \mathrm{ha}^{-1}$ (Table 7).

Generally, at the V6 to R6 growth stages, plant P uptake was not significantly different between zero and

Table 5. Interaction effects of tillage, $\mathrm{N}$ rate, and year on applied $N$ and $P$ recovery by corn plant and grain with manure and fertilizer $\mathbf{N}$ sources.

\begin{tabular}{|c|c|c|c|c|c|}
\hline \multirow{3}{*}{$\begin{array}{l}\text { Growth } \\
\text { stage } \dagger\end{array}$} & \multirow[b]{3}{*}{ Source } & \multicolumn{4}{|c|}{$\boldsymbol{P}>\boldsymbol{F}$} \\
\hline & & \multicolumn{2}{|c|}{ Manure } & \multicolumn{2}{|c|}{ Fertilizer } \\
\hline & & $N$ recovery & $P$ recovery & $N$ recovery & $P$ recover \\
\hline \multirow[t]{4}{*}{ V6 } & tillage $\times \mathbf{N}$ rate & 0.098 & 0.324 & 0.0381 & 0.001 \\
\hline & tillage $\times$ year & 0.786 & 0.102 & 0.0104 & 0.154 \\
\hline & $N$ rate $\times$ year & $<0.0001$ & 0.031 & 0.0001 & $<0.0001$ \\
\hline & $\begin{array}{l}\text { tillage } \times \mathbf{N} \text { rate } \\
\times \text { year }\end{array}$ & 0.491 & 0.181 & 0.0250 & 0.012 \\
\hline \multirow[t]{4}{*}{ V12 } & tillage $\times \mathbf{N}$ rate & 0.007 & 0.147 & 0.1551 & 0.822 \\
\hline & tillage $\times$ year & 0.235 & 0.063 & 0.2379 & 0.058 \\
\hline & $\mathbf{N}$ rate $\times$ year & 0.010 & 0.765 & 0.3857 & 0.051 \\
\hline & $\begin{array}{l}\text { tillage } \times \mathbf{N} \text { rate } \\
\times \text { year }\end{array}$ & 0.075 & 0.078 & 0.5653 & 0.027 \\
\hline \multirow[t]{4}{*}{ VT } & tillage $\times \mathbf{N}$ rate & 0.928 & 0.626 & 0.5054 & 0.969 \\
\hline & tillage $\times$ year & 0.894 & 0.567 & 0.4870 & 0.314 \\
\hline & $N$ rate $\times$ year & $<\mathbf{0 . 0 0 0 1}$ & 0.179 & 0.0903 & 0.723 \\
\hline & $\begin{array}{l}\text { tillage } \times \mathbf{N} \text { rate } \\
\times \text { year }\end{array}$ & 0.267 & 0.352 & 0.7687 & 0.982 \\
\hline \multirow[t]{4}{*}{ R6 } & tillage $\times N$ rate & $<0.0001$ & 0.273 & 0.2602 & 0.002 \\
\hline & tillage $\times$ year & 0.001 & 0.572 & 0.5690 & 0.825 \\
\hline & $N$ rate $\times$ year & $<0.0001$ & 0.001 & 0.0007 & 0.023 \\
\hline & $\begin{array}{l}\text { tillage } \times \mathbf{N} \text { rate } \\
\times \text { year }\end{array}$ & 0.152 & 0.074 & 0.060 & $<\mathbf{0 . 0 0 0 1}$ \\
\hline \multirow[t]{4}{*}{ Grain } & tillage $\times N$ rate & 0.272 & 0.642 & 0.142 & 0.505 \\
\hline & tillage $\times$ year & 0.769 & 0.047 & 0.091 & 0.032 \\
\hline & $N$ rate $\times$ year & 0.197 & 0.24 & 0.001 & 0.726 \\
\hline & $\begin{array}{l}\text { tillage } \times \mathbf{N} \text { rate } \\
\times \text { year }\end{array}$ & 0.493 & 0.018 & 0.642 & 0.793 \\
\hline
\end{tabular}

$\dagger$ V6, sixth-leaf stage of corn; V12, 12th-leaf stage of corn; VT, tassel stage of corn; R6, physiological maturity stage of corn. Total $\mathbf{N}$ determined at R6 for plant biomass only without grain. Significant level $(P \leq 0.05)$. 
Table 6. Corn plant $\mathrm{N}$ and $\mathrm{P}$ uptake with three tillage systems and four $\mathrm{N}$ rates of manure at four growth stages in $2002-2004$.

\begin{tabular}{|c|c|c|c|c|c|c|c|c|c|}
\hline \multirow[b]{2}{*}{ Growth stage $\dagger$} & \multirow[b]{2}{*}{ Tillage system $\nleftarrow$} & \multicolumn{8}{|c|}{$\mathrm{N}$ rate, $\mathrm{kg} \mathrm{ha}^{-1}$} \\
\hline & & $\mathbf{0}$ & 85 & 170 & 250 & $\mathbf{0}$ & 85 & 170 & 250 \\
\hline & & & - N uptak & $\mathrm{ha}^{-1}$ & & & - P upta & $\mathrm{g} \mathrm{ha}^{-1}$ & \\
\hline \multirow[t]{3}{*}{ V6 } & NT & 4.9Ad§ & 12.4ABb & $8.8 B c$ & 16.5ABa & $0.6 \mathrm{Ac}$ & $1.0 \mathrm{Ab}$ & $1.1 \mathrm{Bb}$ & $1.6 \mathrm{Aa}$ \\
\hline & ST & 5.3Ac & $10.7 \mathrm{Bb}$ & $10.6 \mathrm{Bb}$ & 18.7Aa & $0.6 \mathbf{A b}$ & $0.9 \mathbf{A b}$ & $1.4 \mathrm{Aa}$ & $1.3 \mathbf{A a}$ \\
\hline & $\mathbf{C P}$ & 7.5Ab & $14.2 \mathrm{Aa}$ & 15.5Aa & 15.2Ba & $0.7 \mathrm{Ac}$ & $1.2 A b$ & 1.7Aa & $1.5 \mathrm{Aa}$ \\
\hline \multirow[t]{3}{*}{ V12 } & NT & 53.2Ab & $72.3 \mathrm{Bb}$ & 116.9Ba & 97.6Aa & 7.0Ac & $9.1 \mathrm{Bbc}$ & 10.1Bab & 11.9Aa \\
\hline & ST & $55.5 \mathrm{Ab}$ & 109.2Aa & 125.7Aa & 118.4Aa & 7.3Ab & 10.4ABa & 12.2Aa & 12.8Aa \\
\hline & $\mathbf{C P}$ & 69.3Ac & $122.4 \mathrm{Aa}$ & 126.9Aa & 103.3Ab & $7.6 \mathrm{Ab}$ & 11.9Aa & $12.6 \mathrm{Aa}$ & 11.0Aa \\
\hline \multirow[t]{3}{*}{ VT } & NT & $81.8 B c$ & 137.9Bb & $167.5 \mathrm{Ca}$ & 121.7Bb & $12.5 \mathrm{Ab}$ & 16.8Aa & 17.4Ba & 18.1Aa \\
\hline & ST & $76.8 \mathrm{Bc}$ & $151.4 \mathrm{Bb}$ & 188.5Ba & 145.5Ab & 12.1Ab & 17.9Aa & 20.0ABa & 17.3Aa \\
\hline & CP & 101.8Ad & 171.8Ab & 211.7Aa & 141.0Ac & $14.4 \mathrm{Ac}$ & 19.9Ab & 23.1Aa & 17.8Ab \\
\hline \multirow[t]{3}{*}{ R6 } & NT & 69.9ABb & 105.0Ba & 111.0Ba & 108.8ABa & $11.5 \mathrm{Ab}$ & 23.4Ba & 20.2Ba & 23.8Aa \\
\hline & ST & 77.0Ab & 110.6Ba & 108.8Ba & 117.2Aa & $14.4 \mathrm{Ac}$ & 27.3Aa & $19.7 \mathrm{Bb}$ & 22.7Ab \\
\hline & CP & 53.0Bb & 124.5Aa & 138.6Aa & 93.5Bc & 13.8Ac & 27.5Aa & 24.6Aa & $18.7 \mathrm{Bb}$ \\
\hline
\end{tabular}

$\dagger$ V6, sixth-leaf stage of corn; V12, 12th-leaf stage of corn; VT, tassel stage of corn; R6, physiological maturity stage of corn.

\$ NT, no-tillage; ST, strip-tillage; CP, chisel plow. Total N determined at R6 for plant biomass only without grain.

$\$$ Means in columns within each $\mathbf{N}$ rate with the same uppercase letter are not significantly different according to least square means for tillage and $\mathbf{N}$ rate interactions adjusted for multiple comparisons at $P \leq \mathbf{0 . 0 5}$ ). Means in rows within each tillage system with the same lowercase letter are not significantly different according least square means for tillage and $\mathbf{N}$ rate interactions adjusted for multiple comparisons at $P \leq \mathbf{0 . 0 5}$ ).

high $\mathrm{N}$ rates of fertilizer source regardless of the tillage system (Table 7). Plant P uptake exhibited a similar pattern, where corn plant $\mathrm{P}$ uptake in the CP tillage system was greater at the VT growth stage than ST and NT for all $\mathrm{N}$ rates (Table 7). This may be attributed to the effect of tillage on $\mathrm{N}$ and $\mathrm{P}$ availability by increasing soil temperature, increasing crop growth rate early in the season, and increased availability of $\mathrm{N}$ and $\mathrm{P}$ (DevienneBarret et al., 2000; Licht and Al-Kaisi, 2005b). Mallarino et al. (1999) found also that deep banded P (deep or shallow) increased early corn growth and $\mathrm{P}$ uptake more than broadcast placement with NT.

The plant $\mathrm{N}$ uptake at the V12 growth stage across all tillage systems was calculated as a percentage of total $\mathrm{N}$ uptake (grain + plant) using data from Tables 2 and 6 for manure source; the $\mathrm{N}$ uptake was $42,41,50$, and $43 \%$, for $0,85,170$, and $250 \mathrm{~kg} \mathrm{~N}^{-1} \mathrm{~N}$ rates, respectively. Similarly, $\mathrm{N}$ uptake was calculated as a percentage of total $\mathrm{N}$ uptake (grain + plant) using data from Tables 2 and 7 at the V12 growth stage across all tillage systems with fertilizer source; the $\mathrm{N}$ uptake was $41,44,47$, and $41 \%$ for $0,85,170$, and $250 \mathrm{~kg} \mathrm{~N}^{-1}$, respectively. The $\mathrm{P}$ uptake at the V12 growth stage across all tillage systems as a percentage of total $\mathrm{P}$ uptake (grain + plant) was $37,42,41$, and $36 \%$, and $35,33,36$, and $33 \%$ for the above $\mathrm{N}$ rates of manure and fertilizer $\mathrm{N}$ sources, respectively.

\section{Tillage and N Rate Effects on Plant Recovery of Applied $N$ and $P$ at Different Growth Stages}

The recovery of applied $\mathrm{N}$ and $\mathrm{P}$ from both manure and fertilizer sources by corn plant progressively increased with corn growth through VT growth stage (Tables 8 and 9). However, the greatest $\mathrm{N}$ recovery was observed at the $85 \mathrm{~kg} \mathrm{~N} \mathrm{ha}^{-1} \mathrm{~N}$ rate across all tillage systems with both $\mathrm{N}$ sources at the VT growth stage

Table 7. Corn plant $\mathbf{N}$ and $\mathbf{P}$ uptake with three tillage systems and four $\mathbf{N}$ rates of fertilizer at four growth stages in $2002-2004$.

\begin{tabular}{|c|c|c|c|c|c|c|c|c|c|}
\hline \multirow[b]{2}{*}{ Growth stage $\dagger$} & \multirow[b]{2}{*}{ Tillage system $\div$} & \multicolumn{8}{|c|}{$\mathrm{N}$ rate, $\mathrm{kg} \mathrm{ha}^{-1}$} \\
\hline & & $\mathbf{0}$ & 85 & 170 & 250 & $\mathbf{0}$ & 85 & 170 & 250 \\
\hline & & & - N uptak & $\mathrm{ha}^{-1}$ & & 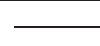 & - P upt & $\mathrm{kg} \mathrm{ha}^{-1}$ & \\
\hline \multirow[t]{3}{*}{ V6 } & NT & 7.1Bb§ & 12.8Ba & 12.2Aa & 11.2Ba & $0.5 \mathrm{Ac}$ & 1.0Aa & 0.8Ab & 1.0Ba \\
\hline & ST & 7.7ABb & 11.8Ba & 11.7Aa & $10.4 \mathrm{Ba}$ & $0.5 \mathrm{Ab}$ & $0.9 B a$ & $0.8 \mathrm{Aa}$ & 0.8Ca \\
\hline & $\mathbf{C P}$ & $9.5 \mathrm{Ac}$ & $16.5 \mathrm{Aa}$ & 12.8Ab & 17.5Aa & 0.6Ad & 1.1Ab & 0.9Ac & $1.3 \mathrm{Aa}$ \\
\hline \multirow[t]{3}{*}{ V12 } & NT & 52.2Ab & 70.8Bb & 110.8Aa & 82.7Aa & $5.2 \mathrm{Ab}$ & 7.4Aa & 7.6Aa & 7.7Aa \\
\hline & ST & 65.1Ac & 115.9Aba & 130.5Aa & 99.6Ab & 5.3Ab & 8.3Aa & 9.4Aa & 7.9Aa \\
\hline & $\mathbf{C P}$ & 70.5Ab & 111.3Aa & 114.2Aa & $106.8 \mathrm{Aa}$ & $6.3 \mathrm{Ab}$ & 9.1Aa & 9.6Aa & 9.1Aa \\
\hline \multirow[t]{3}{*}{ VT } & NT & 87.6Bc & 147.3Bb & 184.8Ba & 151.9Bb & 9.7Bb & 14.7Ba & 14.6Ba & 13.7Ba \\
\hline & ST & 74.0Bc & 149.5Bb & 173.0Bb & 202.8Aa & 10.3Bb & 14.8Ba & $15.2 \mathrm{Ba}$ & 14.9Ba \\
\hline & $\mathbf{C P}$ & 117.1Ac & 191.4Aba & 213.7Aa & 159.9Bb & 13.0Ab & 17.5Aa & 19.3Aa & 18.4Aa \\
\hline \multirow[t]{3}{*}{ R6 } & NT & 52.9Ac & 94.0Aab & 113.4Ba & 77.7Ab & 6.0Ab & $15.8 \mathrm{Aa}$ & 12.9ABa & 12.2Aa \\
\hline & ST & 42.3Ab & 91.1Aa & 96.8Ba & 89.9Aa & 5.8Ab & 13.9Aa & 8.3Bb & 13.5Aa \\
\hline & $\mathbf{C P}$ & 53.2Ac & $79.4 \mathrm{Ab}$ & 124.4Aa & $74.3 \mathrm{Ab}$ & 4.9Ab & 8.8Bb & $16.3 \mathrm{Aa}$ & $9.2 \mathrm{Ab}$ \\
\hline
\end{tabular}

$\dagger$ V6, sixth-leaf stage of corn; V12, 12th-leaf stage of corn; VT, tassel stage of corn; R6, physiological maturity stage of corn.

$\$$ NT, no-tillage; ST, strip-tillage; CP, chisel plow. Total N determined at R6 for plant biomass only without grain.

$\$$ Means in columns within each $\mathbf{N}$ rate with the same uppercase letter are not significantly different according to least square means for tillage and $\mathbf{N}$ rate interactions adjusted for multiple comparisons at $P \leq 0.05$ ). Means in rows within each tillage system with the same lowercase letter are not significantly different according least square means for tillage and $\mathrm{N}$ rate interactions adjusted for multiple comparisons at $P \leq 0.05$ ). 
Table 8. Corn plant $N$ and $P$ recovery with various tillage systems and $N$ rates of manure at four growth stages in $2002-2004$.

\begin{tabular}{|c|c|c|c|c|c|c|c|c|c|}
\hline \multirow[b]{2}{*}{ Growth stage $\dagger$} & \multirow[b]{2}{*}{ Tillage system } & \multicolumn{8}{|c|}{$\mathrm{N}$ rate, $\mathrm{kg} \mathrm{ha}^{-1}$} \\
\hline & & $\mathbf{0}$ & 85 & 170 & 250 & $\mathbf{0}$ & 85 & 170 & 250 \\
\hline & & - & 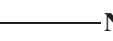 & very, $\%$ & {[} & & $\mathbf{P}$ & ery, \%- & \\
\hline \multirow[t]{3}{*}{ V6 } & NT & - & 8.9Aa§ & $2.3 \mathrm{Ab}$ & 4.7Ab & - & $0.7 \mathrm{ABa}$ & $0.4 \mathrm{Bb}$ & $0.5 \mathrm{Aab}$ \\
\hline & ST & - & $6.4 \mathrm{Ba}$ & 3.1Ab & $5.3 \mathrm{Aa}$ & - & $0.5 \mathrm{Ba}$ & $0.6 \mathrm{ABa}$ & $0.4 \mathrm{Aa}$ \\
\hline & CP & - & 7.9Aa & 4.7Ab & 3.1Ab & - & 0.9Aa & 0.9Aa & $0.5 \mathbf{A b}$ \\
\hline \multirow[t]{3}{*}{ V12 } & NT & - & $22.4 \mathrm{Bb}$ & 37.4Aa & 17.7ABb & - & 3.8Ba & $2.8 \mathrm{Aa}$ & $2.8 \mathrm{Aa}$ \\
\hline & ST & - & 63.2Aa & 41.3Ab & 25.1Ac & - & $5.5 \mathrm{ABa}$ & 4.3Aa & 3.1Ab \\
\hline & $\mathbf{C P}$ & - & $62.5 \mathrm{Aa}$ & 33.9Ab & $13.6 \mathrm{Bc}$ & - & 7.5Aa & $4.4 \mathrm{Ab}$ & 1.9Ac \\
\hline \multirow[t]{3}{*}{ VT } & NT & - & 66.0Ba & 50.4Aa & $16.0 \mathrm{Bb}$ & - & $7.4 \mathrm{Aa}$ & 4.3Ab & 3.1Ab \\
\hline & ST & - & 87.7Aa & 65.7Ab & $27.5 \mathrm{Ac}$ & - & $9.7 \mathrm{Aa}$ & $6.9 \mathrm{Ab}$ & 2.9Ac \\
\hline & CP & - & 82.4Aa & 64.7Ab & $15.7 \mathrm{Bc}$ & - & 9.8Aa & 7.7Ab & 1.9Ac \\
\hline \multirow[t]{3}{*}{ R6 } & NT & - & 41.3Ba & 24.2Bb & $15.6 \mathrm{Ac}$ & - & 21.3Aa & 7.7Ab & 6.9Ab \\
\hline & ST & - & 39.6Ba & $18.7 \mathrm{Bb}$ & 16.1Ab & - & 23.1Aa & 4.7Ab & 4.7Ab \\
\hline & CP & - & 84.1Aa & 50.3Ab & $16.2 \mathrm{Ac}$ & - & 24.5Aa & $9.6 \mathrm{Ab}$ & $2.8 \mathrm{Ac}$ \\
\hline
\end{tabular}

$\dagger$ V6, sixth-leaf stage of corn; V12, 12th-leaf stage of corn; VT, tassel stage of corn; R6, physiological maturity stage of corn.

$\$$ NT, no-tillage; ST, strip-tillage; CP, chisel plow.

$\S$ Means in columns within each $\mathbf{N}$ rate with the same uppercase letter are not significantly different according to least square means for tillage and $\mathbf{N}$ rate interactions adjusted for multiple comparisons at $P \leq \mathbf{0 . 0 5}$ ). Means in rows within each tillage system with the same lowercase letter are not significantly different according least square means for tillage and $\mathrm{N}$ rate interactions adjusted for multiple comparisons at $P \leq \mathbf{0 . 0 5}$ ).

(Tables 8 and 9). Generally, increased $\mathrm{N}$ rate resulted in a decrease in plant $\mathrm{N}$ and $\mathrm{P}$ recovery with all tillage systems.

The low recovery of $\mathrm{P}$ by the corn plant at all growth stages with both manure and fertilizer sources may be attributed to the lack of corn response to any additional $\mathrm{P}$ application due to high soil $\mathrm{P}$ test $\left(>35 \mathrm{mg} \mathrm{kg}^{-1}\right)$. It was found that $\mathrm{P}$ absorption by soil particles in surface layers in NT are often reduced compared with $\mathrm{CP}$, where soil surface disturbance helped incorporate $\mathrm{P}$ and increase opportunities for soil-P reaction (Edwards et al., 1988; Guertal et al., 1991). It was always believed that NT might have a disadvantage in nutrient availability and the need for additional $\mathrm{N}$ and $\mathrm{P}$ applications compared with CT systems. However, these findings showed the limited effect that increased $\mathrm{N}$ or $\mathrm{P}$ applications have on increasing the utilization or recovery of these two nutrients by corn grown in all tillage systems.

\section{Effects of Tillage, $\mathbf{N}$ Rate, and Season Interactions on Plant $\mathbf{N}$ and $P$ Uptake and Recovery}

The interactions of tillage $\times \mathrm{N}$ rate, tillage $\times$ year, and $\mathrm{N}$ rate $\times$ year had a significant effect on plant $\mathrm{N}$ and $\mathrm{P}$ uptake during the early growth stage (V6), but tillage $X$ $\mathrm{N}$ rate $\times$ year had only a significant effect on plant $\mathrm{P}$ uptake with fertilizer source (Table 4). Changes in soil conditions because of different tillage along with seasonal variability may contribute to the change in $\mathrm{N}$ and $\mathrm{P}$ availability early in the growing season. Thus, a significant tillage effect on plant $\mathrm{N}$ uptake could often be observed during the early parts of the growing season

Table 9. Corn plant $N$ and $P$ recovery with various tillage systems and $N$ rates of fertilizer at four growth stages in $2002-2004$.

\begin{tabular}{|c|c|c|c|c|c|c|c|c|c|}
\hline \multirow[b]{2}{*}{ Growth stage $\dagger$} & \multirow[b]{2}{*}{ Tillage system } & \multicolumn{8}{|c|}{$\mathrm{N}$ rate, $\mathrm{kg} \mathrm{ha}^{-1}$} \\
\hline & & $\mathbf{0}$ & 85 & 170 & 250 & $\mathbf{0}$ & 85 & 170 & 250 \\
\hline & & - & $-\mathbf{N}$ & ery, \% & - & - & $-\mathrm{I}$ & ery, \% - & \\
\hline \multirow[t]{3}{*}{ V6 } & NT & - & 6.7Aaß & 3.0Ab & $1.6 \mathrm{Bc}$ & - & $1.8 \mathrm{Aa}$ & $\mathbf{0 . 8 A b}$ & $1.6 B a$ \\
\hline & ST & - & $4.9 \mathrm{Ba}$ & $2.3 \mathbf{A b}$ & $1.1 \mathrm{Bb}$ & - & $1.2 \mathbf{B a}$ & 1.0Aa & $1.0 \mathrm{Ca}$ \\
\hline & $\mathbf{C P}$ & - & 8.2Aa & 1.9Ab & $3.2 \mathrm{Ab}$ & - & $1.5 \mathrm{ABb}$ & $0.9 \mathrm{Ac}$ & $2.2 \mathrm{Aa}$ \\
\hline \multirow[t]{3}{*}{ V12 } & NT & - & 21.9Bb & 34.5Aa & $12.2 \mathrm{Ac}$ & - & 7.7Aa & $8.3 \mathrm{Ba}$ & 8.7Aa \\
\hline & ST & - & 59.8Aa & 38.5Ab & 13.8Ac & - & $10.3 \mathbf{A b}$ & $14.2 \mathrm{Aa}$ & 8.9Ab \\
\hline & $\mathbf{C P}$ & - & 48.0Aa & 25.7Ab & $14.5 \mathrm{Ac}$ & - & $9.8 \mathrm{Aa}$ & $11.5 \mathrm{Aa}$ & $9.7 \mathrm{Aa}$ \\
\hline \multirow[t]{3}{*}{ VT } & NT & - & $70.2 \mathrm{Aa}$ & $57.1 \mathrm{Ab}$ & $25.7 \mathrm{Bc}$ & - & 17.3Aa & 16.9Aa & 13.7Ab \\
\hline & ST & - & 88.8Aa & $58.2 \mathrm{Ab}$ & 51.5Ab & - & $15.4 \mathrm{Aa}$ & 17.0Aa & 15.8Aa \\
\hline & $\mathbf{C P}$ & - & 87.3Aa & $56.8 \mathrm{Ab}$ & $17.1 \mathrm{Bc}$ & - & $15.5 \mathrm{Ab}$ & $21.5 \mathrm{Aa}$ & 18.4Aab \\
\hline \multirow[t]{3}{*}{ R6 } & NT & - & 48.3Aa & 35.6Ab & $9.9 \mathrm{Bc}$ & - & 33.8Aa & 23.5Bb & 21.1ABb \\
\hline & ST & - & 57.4Aa & 32.1Ab & $19.0 \mathrm{Ac}$ & - & 27.9Aa & $8.4 \mathrm{Cb}$ & 26.6Aa \\
\hline & CP & - & $30.8 \mathrm{Bb}$ & 41.9Aa & $8.4 \mathrm{Bc}$ & - & $13.7 \mathrm{Bb}$ & 39.5Aa & $14.9 \mathrm{Bb}$ \\
\hline
\end{tabular}

$\dagger$ V6, sixth-leaf stage of corn; V12, 12th-leaf stage of corn; VT, tassel stage of corn; R6, physiological maturity stage of corn.

$\leftarrow$ NT, no-tillage; ST, strip-tillage; CP, chisel plow.

$\S$ Means in columns within each $\mathbf{N}$ rate with the same uppercase letter are not significantly different according to least square means for tillage and $\mathbf{N}$ rate interactions adjusted for multiple comparisons at $P \leq \mathbf{0 . 0 5}$ ). Means in rows within each tillage system with the same lowercase letter are not significantly different according least square means for tillage and $\mathrm{N}$ rate interactions adjusted for multiple comparisons at $P \leq 0.05$ ). 
(Dharmakeerthi et al., 2006). The interaction effect of tillage $\times \mathrm{N}$ rate, tillage $\times$ year, and $\mathrm{N}$ rate $\times$ year after the V6 growth stage on plant $\mathrm{N}$ and $\mathrm{P}$ uptake was inconsistent with both $\mathrm{N}$ sources. These interaction effects on plant $\mathrm{N}$ and $\mathrm{P}$ uptake were insignificant, particularly late in the season where tillage systems have very limited effect on plant $\mathrm{N}$ or $\mathrm{P}$ uptake. These observations are similar to those by Dharmakeerthi et al. (2006), where plant $\mathrm{N}$ uptake between $\mathrm{V} 6$ growth stage and silking is not significantly affected by tillage system. The few cases of increase in plant $\mathrm{N}$ and $\mathrm{P}$ uptake that were observed with $\mathrm{CP}$ tillage system with both $\mathrm{N}$ sources is highly related to soil temperature increase and enhanced early plant growth compared with NT (data not presented). The cool soil conditions associated with the NT system tend to reduce early plant growth and nutrient uptake (Licht and Al-Kaisi, 2005b; Kaspar et al., 1990). It was observed that at the $\mathrm{R} 6$ all interactions of tillage, $\mathrm{N}$ rate, and year in affecting plant $\mathrm{N}$ and $\mathrm{P}$ uptake were inconsistent with both $\mathrm{N}$ sources. Tillage $\times \mathrm{N}$ rate and $\mathrm{N}$ rate $\times$ year were significant at the $\mathrm{R} 6$ growth stage in affecting plant $\mathrm{N}$ and $\mathrm{P}$ uptake with manure source, and only $\mathrm{N}$ rate $\times$ year was significant in affecting plant $\mathrm{N}$ uptake with fertilizer source (Table 4). The three-way interaction of tillage, $\mathrm{N}$ rate, and year had a significant effect on plant P uptake at the V6 growth stage with fertilizer $\mathrm{N}$ source and at the R6 growth stage with both $\mathrm{N}$ sources (Table 4). These interactions indicate that the $\mathrm{N}$ rate and seasonal variability have more effect on plant $\mathrm{N}$ and $\mathrm{P}$ uptake later in the growing season than the tillage system. Dharmakeerthi et al. (2006) found that $\mathrm{N}$ uptake was affected by fertilizer $\mathrm{N}$ management during the V6 growth stage to maturity.

The only significant interaction in affecting plant $\mathrm{N}$ and $\mathrm{P}$ recovery of applied $\mathrm{N}$ and $\mathrm{P}$ was tillage $\times \mathrm{N}$ rate at the V6 growth stage with both $\mathrm{N}$ sources (manure and fertilizer). It was observed that 31,13 , and $69 \%$ of the two-way interactions of tillage $\times \mathrm{N}$ rate, tillage $\times$ year, and $\mathrm{N}$ rate $\times$ year, respectively, have a significant effect $(P<0.05)$ on $\mathrm{N}$ and $\mathrm{P}$ recovery from $\mathrm{V} 6$ to $\mathrm{R} 6$ growth stages (Table 5). However, only $25 \%$ of the three-way interaction effects of tillage $\times \mathrm{N}$ rate $\times$ year on $\mathrm{N}$ and $\mathrm{P}$ recovery were significant $(P<0.05)$ from V6 to R6 growth stages (Table 5).

\section{Tillage and N Rate Effects on Fall Corn Stalk $\mathrm{NO}_{3}-\mathrm{N}$ Concentration}

Three-year averages of fall corn stalk $\mathrm{NO}_{3}-\mathrm{N}$ concentration increased linearly with increasing $\mathrm{N}$ application rate with both $\mathrm{N}$ sources regardless of tillage system (Fig. 1a and 1b). The relationship between corn stalk $\mathrm{NO}_{3}-\mathrm{N}$ concentration and $\mathrm{N}$ application rate within each tillage system of both $\mathrm{N}$ sources is well described by linear functions, but not significantly different in slopes with manure source. This relationship also explains the effect of each tillage system on potential $\mathrm{NO}_{3}-\mathrm{N}$ accumulation in corn stalks at maturity, where corn stalks had similar $\mathrm{NO}_{3}-\mathrm{N}$ concentrations (Fig. 1a). The slopes of linear functions with manure source are not significantly different $(P<0.05)$, which means the rate of

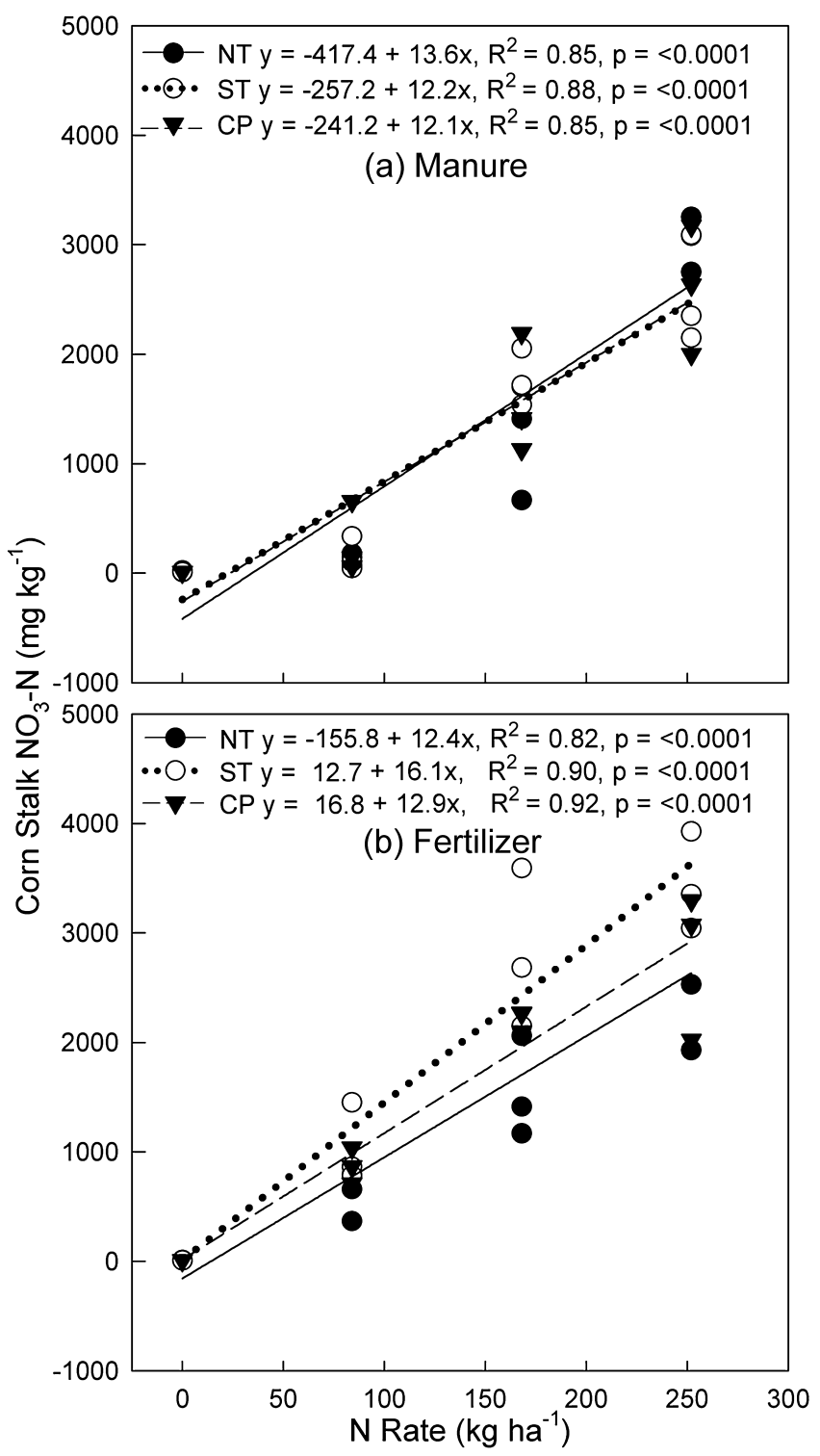

Fig. 1. Fall corn stalk $\mathrm{NO}_{3}-\mathrm{N}$ concentration as a function of $\mathrm{N}$ rate of manure and fertilizer treatments with three tillage systems over 3 yr.

$\mathrm{NO}_{3}-\mathrm{N}$ accumulation is identical with all tillage systems. Fall stalk $\mathrm{NO}_{3}-\mathrm{N}$ concentration and slope were highest in the ST system for the fertilizer source at the 170 and $250 \mathrm{~kg} \mathrm{~N}$ ha ${ }^{-1} \mathrm{~N}$ rate compared with NT and CP (Fig. 1b).

The intercept of different tillage linear functions of manure and fertilizer sources indicates that stalk $\mathrm{NO}_{3}-\mathrm{N}$ accumulation is much lower with NT than that with ST and CP. This may be attributed to the influence of tillage system on $\mathrm{N}$ mineralization and the increase of potential $\mathrm{N}$ availability, where ST and $\mathrm{CP}$ can contribute to the increase of soil temperature compared with NT (Licht and Al-Kaisi, 2005b; Doran, 1980). Generally, the high N rate application caused an increase in corn stalk $\mathrm{NO}_{3}-\mathrm{N}$ concentration above the critical range of $750-2000 \mathrm{mg} \mathrm{kg}^{-1}$ (Macy, 1936; Blackmer and Mallarino, 1996) in corn plants, and luxury $\mathrm{N}$ consumption by corn was observed with both $\mathrm{N}$ sources and tillage systems. The greater $\mathrm{NO}_{3}-\mathrm{N}$ accumulation as $\mathrm{N}$ rate increases indicates the 
inefficient $\mathrm{N}$ utilization for grain production leading to luxury $\mathrm{N}$ consumption and accumulation in stalks from over $\mathrm{N}$ application. The maximum corn stalk $\mathrm{NO}_{3}-\mathrm{N}$ concentration with manure source occurred at $250 \mathrm{~kg}$ $\mathrm{N} \mathrm{ha}^{-1}$ for all tillage systems, while it occurred at 170 and $250 \mathrm{~kg} \mathrm{~N}^{-1}$ with ST and at $250 \mathrm{~kg} \mathrm{~N} \mathrm{ha}^{-1}$ with NT and $\mathrm{CP}$. The results revealed that regardless of tillage system, $\mathrm{NO}_{3}-\mathrm{N}$ accumulation in corn stalks with manure was in the same range in response to $\mathrm{N}$ application rate.

\section{Tillage and $\mathbf{N}$ Rate Effects on Late Spring Soil $\mathrm{NO}_{3}-\mathrm{N}$ Concentration}

The relationship between soil $\mathrm{NO}_{3}-\mathrm{N}$ concentration in the top $30 \mathrm{~cm}$ of soil and $\mathrm{N}$ rate of manure and fertilizer sources of 3-yr averages of the three tillage systems was poorly described by a linear function $(P<0.05)$, except for NT with manure source and ST with fertilizer $\mathrm{N}$ source (Fig. 2a and 2b). The relationship was equally poorly described by nonlinear function as well (data not presented). The weak relationship between soil $\mathrm{NO}_{3}-\mathrm{N}$ concentration and $\mathrm{N}$ rate is most likely due to high spatial variability of soil $\mathrm{NO}_{3}-\mathrm{N}$ concentration. The slopes of the linear functions of the three tillage systems with manure are similar $(P<0.05)$ (Fig. 2a), which indicates a similar effect of all tillage systems on $\mathrm{NO}_{3}-\mathrm{N}$ concentration in soil. However, differences in slopes of different tillage systems were more pronounced with fertilizer source, where it was greater with ST compared with both NT and CP slopes $(P<0.05)$ (Fig. 2b). The concentration of $\mathrm{NO}_{3}-\mathrm{N}$ was low during early spring in 2002 and 2004, which is most likely caused by some deep leaching of $\mathrm{NO}_{3}-\mathrm{N}$ due to above normal rainfall in early April (approximately $2.70 \mathrm{~cm}$ ) (local weather station at the research farm). At all manure $\mathrm{N}$ rates, tillage systems did not cause significant differences in late spring soil $\mathrm{NO}_{3}-\mathrm{N}$ concentration (Fig. 2a). Soil $\mathrm{NO}_{3}-\mathrm{N}$ concentration of ST with fertilizer source was greater than that under both the NT and CP systems at the N rates of 170 and $250 \mathrm{~kg} \mathrm{~N} \mathrm{ha}^{-1}$ at the top $30 \mathrm{~cm}$ (Fig. 2b). The high spatial and seasonal variability effect on soil $\mathrm{NO}_{3}-\mathrm{N}$ concentration with both manure and fertilizer sources with all tillage systems is very evident and clearly highlights the inconsistency of tillage effect on $\mathrm{NO}_{3}-\mathrm{N}$ status, and therefore, the reliability of this test for $\mathrm{N}$ application recommendations.

However, some studies have shown that CT systems can lead to an increase in soil $\mathrm{NO}_{3}-\mathrm{N}$ concentration in the soil profile due to rapid mineralization of organic-N compared with the NT system (Philips et al., 1980; Brandt, 1992; Huntington et al., 1985; McCarthy et al., 1995; Halvorson et al., 2001; Sanju and Singh, 2001). These study results showed a significant effect for tillage systems on soil $\mathrm{NO}_{3}-\mathrm{N}$ concentration with either $\mathrm{N}$ source, except for ST with fertilizer N source.

\section{CONCLUSIONS}

The findings of this research showed that regardless of the $\mathrm{N}$ source and tillage system, corn yield did not

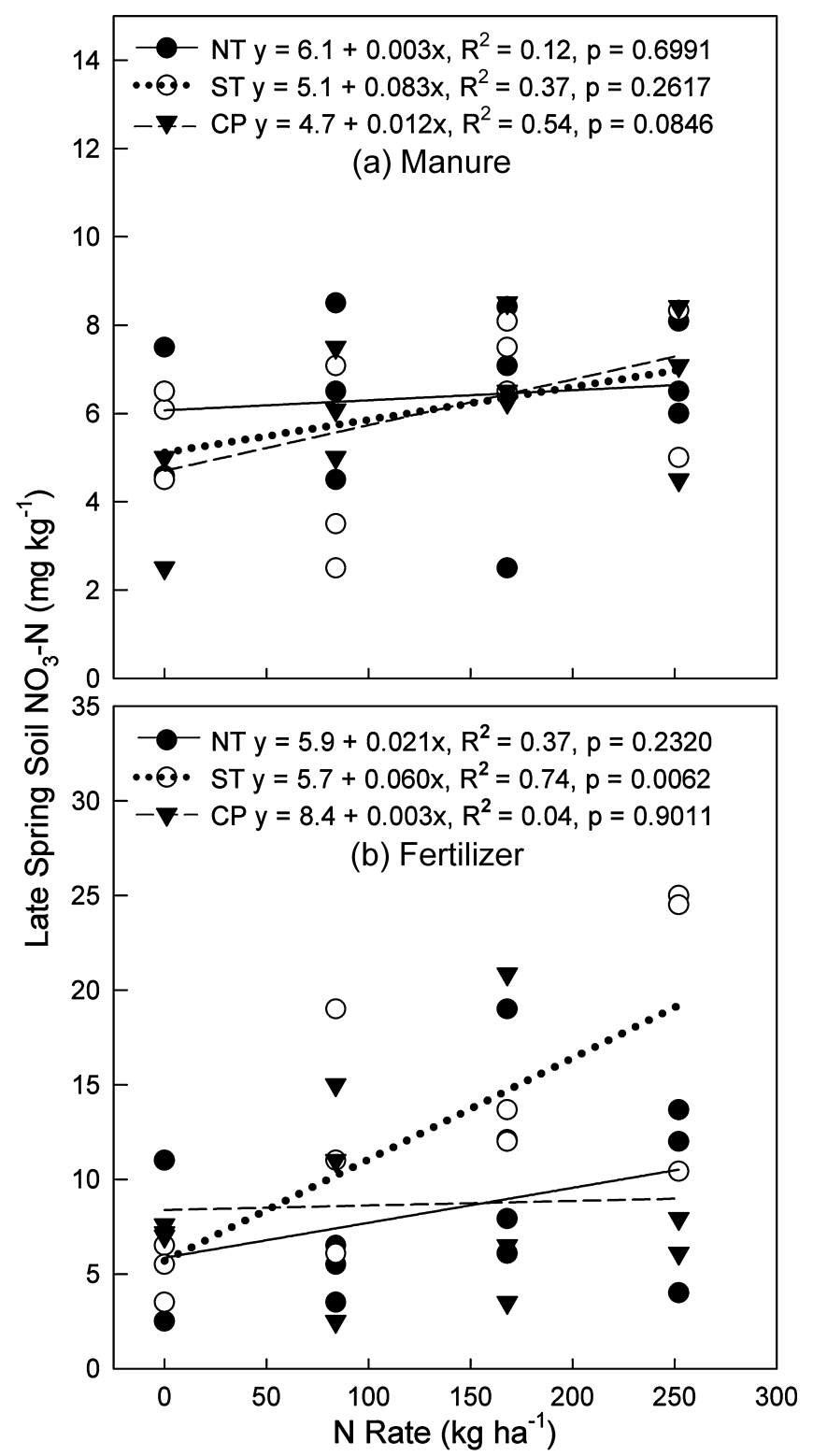

Fig. 2. Late spring soil $\mathrm{NO}_{3}-\mathrm{N}$ concentration as a function of $\mathrm{N}$ rate of manure and fertilizer treatments with three tillage systems over 3 yr.

increase significantly with increasing $\mathrm{N}$ rate application above $85 \mathrm{~kg} \mathrm{~N} \mathrm{ha}^{-1}$. The effect of tillage system on grain $\mathrm{N}$ uptake at different $\mathrm{N}$ rates with both $\mathrm{N}$ sources was generally insignificant, except with fertilizer source, where ST had improved N uptake compared with NT and $\mathrm{CP}$ for the 0 and $85 \mathrm{~kg} \mathrm{~N} h a^{-1}$ rates. The interaction effect of tillage $\times \mathrm{N}$ rate on grain $\mathrm{N}$ and $\mathrm{P}$ uptake was inconsistent, except for $\mathrm{N}$ uptake with fertilizer source. Across all tillage systems and $\mathrm{N}$ rates, plant $\mathrm{N}$ and $\mathrm{P}$ uptake percentages at the V12 growth stage represent 44 and $39 \%$ of total plant + grain $\mathrm{N}$ uptake, respectively with manure source, and 43 and $34 \%$, respectively with fertilizer source.

The tillage $\times \mathrm{N}$ rate effect on plant $\mathrm{N}$ and $\mathrm{P}$ recovery was only significant at the V6 growth stage with both $\mathrm{N}$ sources. However, most dominant interaction effect on plant $\mathrm{N}$ and $\mathrm{P}$ uptake and recovery was $\mathrm{N}$ rate $\times$ year 
from the V6 to R6 growth stages. This significant interaction effect on plant $\mathrm{N}$ and $\mathrm{P}$ uptake and recovery was consistent with both $\mathrm{N}$ sources at the V6 and R6 growth stages. This indicates that seasonal variability has more effect on $\mathrm{N}$ availability than the type of tillage system. The three-way interaction effect of tillage $\times \mathrm{N}$ rate $\times$ year on plant $\mathrm{N}$ and $\mathrm{P}$ recovery was generally insignificant, and only $25 \%$ of this interaction was significant from the V6 to R6 growth stages.

Regardless of $\mathrm{N}$ source, the interaction effect of tillage $\times \mathrm{N}$ rates influenced both corn stalk $\mathrm{NO}_{3}-\mathrm{N}$ and soil $\mathrm{NO}_{3}-\mathrm{N}$ concentrations. Generally, the relationships between either corn stalk $\mathrm{NO}_{3}-\mathrm{N}$ concentration and the $\mathrm{N}$ application rate of both $\mathrm{N}$ sources was linear, increasing with the increase of $\mathrm{N}$ rate in all tillage systems. The soil $\mathrm{NO}_{3}-\mathrm{N}$ and $\mathrm{N}$ rate showed a poor correlation due to high spatial variability of soil $\mathrm{NO}_{3}-\mathrm{N}$ concentration. The interaction between tillage and $\mathrm{N}$ rate was inconsistent in influencing plant $\mathrm{N}$ and $\mathrm{P}$ uptake by corn plant and grains, but high $\mathrm{N}$ rates have an influence on yield response and corn stalk $\mathrm{NO}_{3}-\mathrm{N}$ concentration regardless of the tillage system. The findings suggest that both $\mathrm{N}$ sources have a similar effect on yield and $\mathrm{N}$ and $\mathrm{P}$ uptake regardless of tillage type. Additional $\mathrm{N}$ application from both $\mathrm{N}$ sources did not increase $\mathrm{N}$ uptake or yield for one particular tillage system over another. The findings of this study also indicate that the most effect a tillage system can have on plant $\mathrm{N}$ and $\mathrm{P}$ uptake was early in the growing season with both $\mathrm{N}$ sources, and it had a limited effect on plant $\mathrm{N}$ and $\mathrm{P}$ uptake later in the growing season. It was always believed that NT might have a disadvantage in nutrient availability and the need for additional $\mathrm{N}$ and $\mathrm{P}$ applications compared with $\mathrm{CT}$ systems. However, these findings showed the limited effect that increased $\mathrm{N}$ or $\mathrm{P}$ application has on increasing the utilization or recovery of these two nutrients by corn grown with all tillage systems. Furthermore, the most dominant or significant two-way interaction effect on plant $\mathrm{N}$ and $\mathrm{P}$ uptake or recovery was $\mathrm{N}$ rate $\times$ year rather than tillage $\times \mathrm{N}$ rate or tillage $\times$ year interactions. Another interesting observation from these results is the similarity of nutrient value of both $\mathrm{N}$ sources and corn response to these two $\mathrm{N}$ sources across all tillage systems.

\section{REFERENCES}

Al-Kaisi, M., and M.A. Licht. 2004. Effect of strip tillage on corn nitrogen uptake and residual soil nitrate accumulation compared with no-tillage and chisel plow. Agron. J. 96:1164-1171.

Al-Kaisi, M.M., and R.M. Waskom. 2002. Utilizing swine effluent for sprinkler-irrigated corn production. J. Soil Water Conserv. 57: 111-120.

Al-Kaisi, M.M., and X. Yin. 2003. Effects of nitrogen rate, irrigation rate, and plant population on corn and water use efficiency. Agron. J. 95:1475-1482.

AOAC. 1997. Phosphorus in animal feed and pet food. Photometric method. p. 35-36. In P. Cunniff (ed.) Official methods of analysis. 16th ed. AOAC Int., Gaithersburg, MD.

Blackmer, A.M., and A.P. Mallarino. 1996. Corn testing to evaluate nitrogen management. Ext. Publ. PM 1584. Iowa State Univ., Ames.

Blackmer, A.M., R.D. Voss, and A.P. Mallarino. 1997. Nitrogen fertilizer recommendations for corn in Iowa. Ext. Publ. PM-1714. Iowa State Univ., Ames.
Brandt, S.A. 1992. Zero vs. conventional tillage and their effects on crop yield and soil moisture. Can. J. Plant Sci. 72:679-688.

Bray, R.H., and L.T. Kurtz. 1945. Determination of total organic and available forms of phosphorous in soil. Soil Sci. 59:39-45.

Carter, M.R., and D.A. Rennie. 1987. Effects of tillage and deposition and utilization of ${ }^{15} \mathrm{~N}$ residual fertilizer. Soil Tillage Res. 9:33-43.

Cerrato, M.E., and A.M. Blackmer. 1990. Relationships between grain nitrogen and nitrogen status of corn. Agron. J. 82:744-749.

deMooy, C.J., J.L. Young, and J.D. Kaap. 1973. Comparative response of soybeans and corn to phosphorus and potassium. Agron. J. 65 : 851-855.

Devienne-Barret, F., E. Justes, J.M. Machet, and B. Mary. 2000. Integrated control of nitrate uptake by crop growth rate and soil nitrate availability under field conditions. Ann. Bot. 86:995-1005.

Dharmakeerthi, R.S., B.D. Kay, and E.G. Beauchamp. 2006. Spatial variability of in-season nitrogen uptake by corn across a variable landscape as affected by management. Agron. J. 98:255-264.

Dinnes, D.L., D.L. Karlen, D.B. Jaynes, T.C. Kasper, J.L. Hatfield, T.S Colvin, and C.A. Cambardella. 2002. Nitrogen management strategies to reduce nitrate leaching in tile-drained Midwestern soils. Agron. J. 94:153-171

Doran, J.W. 1980. Soil microbial and biochemical changes associated with reduced tillage. Soil Sci. Soc. Am. J. 44:765-771.

Edwards, J.H., D.L. Thurlow, and J.T. Eason. 1988. Influence of tillage and crop rotation on yields of corn, soybean and wheat. Agron. J. 80:76-80.

EPA. 1974. Nitrogen, nitrate-nitrite (spectrophotometer, cadmium reduction). p. 1-6. In Method 353.3. Rep. 600/4-79-02. EPA, Washington, DC.

EPA. 1986. Potassium (atomic absorption, direct aspiration). p. 1-3. In Method 7610. Rep. 600/4-82-055. EPA, Washington, DC.

Gilliam, J.W., and G.D. Hoyt. 1987. Effect of conservation tillage on fate and transport of nitrogen. p. 217-240. In T. J. Logan (ed.) Effects of conservation tillage on ground water quality: Nitrates and pesticides. Lewis Publ., Chelsea, MI.

Griffith, D.R., J.V. Mannering, and W.C. Moldenhauer. 1977. Conservation tillage in the eastern corn belt. J. Soil Water Conserv. 32: $22-28$

Groffman, P.M., P.F. Hendrix, and D.A. Crossley, Jr. 1987. Nitrogen dynamics in conventional and no-tillage agrosystems with inorganic fertilizer legume inputs. Plant Soil 07:315-322.

Guertal, E.A., D.J. Eckert, S.J. Traina, and T.J. Logan. 1991. Differential phosphorus retention in soil profiles under no-till crop production. Soil Sci. Soc. Am. J. 55:410-413.

Halvorson, A.D., B.J. Wienhold, and A.L. Black. 2001. Tillage and nitrogen fertilization influence and soil nitrogen in an annual cropping system. Agron. J. 93:836-841.

House, G.J., B.R. Stinner, D.A. Crossley, Jr., E.P. Odum, and G.W. Langdale. 1984. Nitrogen cycling in conventional and no-tillage agrosystems in the southern Piedmont. J. Soil Water Conserv. 39: 194-200.

Huntington, T.G., J.H. Grove, and W.W. Frye. 1985. Release and recovery of nitrogen from winter annual crops in no-till corn production. Commun. Soil Sci. Plant Anal. 16:193-211.

Kane, P.F. 1999. Method 987.02: Nitrogen (total) in fertilizers. p. 13-14. In P. Cunniff (ed.) Official methods of analysis. 16th ed. AOAC Int., Gaithersburg, MD

Karlen, D.L., E.C. Berry, T.S. Colvin, and R.S. Kanwar. 1991. Twelve year tillage and crop rotation effects on yields and soil chemical properties in Northeast Iowa. Commun. Soil Sci. Plant Anal. 22: 1985-2003.

Kaspar, T.C., D.C. Erbach, and R.M. Cruse. 1990. Corn response to seed-row residue removal. Soil Sci. Soc. Am. J. 54:1112-1117.

Ketchenson, W.J. 1980. Effect of tillage on fertilizer requirements for corn on silt loam soil. Agron. J. 72:540-542.

Licht, M.A., and M. Al-Kaisi. 2005a. Corn response, nitrogen uptake and water use in strip-tillage compared with no-tillage and chisel plow. Agron. J. 97:705-710.

Licht, M., and M. Al-Kaisi. 2005b. Strip-tillage effect on seedbed soil temperature and other soil physical properties. Soil Tillage Res. J. 80:233-249.

Macy, P. 1936. The quantitative mineral nutrient requirements of plants. Plant Physiol. 11:749-764. 
Mallarino, A.P., J.M. Bordoli, and R. Borges. 1999. Phosphorus and potassium placement effects on early growth and nutrient uptake of no-tillage corn in relationships with grain yield. Agron. J. 91:37-45.

Mallarino, A.P., J.R. Webb, and A.M. Blackmer. 1991. Corn and soybean yields during 11 years of phosphorus and potassium fertilization on a high-testing soil. J. Prod. Agric. 4:312-317.

McCarthy, G.W., J.J. Meisinger, and F.M. Jenninskiens. 1995. Relationship between total-N, biomass-N and active-N under different tillage systems and $\mathrm{N}$ fertilizer treatments. Soil Biol. Biochem. 27: $1245-1250$.

McLean, E.O. 1982. Soil pH and lime requirement. p. 199-224. In A.L. Page et al. (ed.) Methods of soil analysis. Part 2. 2nd ed. Agron. Monogr. 9. ASA and SSA, Madison, WI.

Mehdi, B.B., C.A. Madramootoo, and G.R. Mehuys. 1999. Yield and nitrogen content of corn under different tillage practices. Agron. J. 91:631-636.

Mullins, G.L., S.E. Alley, and D.W. Reeves. 1998. Tropical maize response to nitrogen and starter fertilizer under strip and conventional tillage systems in southern Alabama. Soil Tillage Res. 45:1-15.

Mulvaney, R.L. 1996. Nitrogen-inorganic forms. p. 1123-1184. In D.L. Sparks (ed.) Methods of soil analysis. Part 3-Chemical methods. SSSA Book Ser. No. 5. SSSA and ASA, Madison, WI.

Obreza, T.A., and F.M. Rhoads. 1988. Irrigated corn response to soil test indices and fertilizer nitrogen, phosphorus, potassium and magnesium. Soil Sci. Soc. Am. J. 52:701-706.

Ortiz-Monasterio, J.J., R.J. Peńa, W.H. Pfeiffer, and A.H. Hede. 2002. Phosphorus use efficiency, grain yield and quality of triticale and durum wheat under irrigated conditions. Proc. of the 5th Int. Triticale Symp., Annex. 30 June-5 July 2002. Radzików, Poland.
Payne, W.A., L.R. Hossner, A.B. Onken, and C.W. Wendt. 1995. Nitrogen and phosphorus uptake in pearl millet and its relation to nutrient and transpiration efficiency. Agron. J. 87:425-431.

Philips, R.E., R.L. Blevins, G.W. Thomas, W.W. Frye, and S.H. Philip. 1980. No-tillage agriculture. Science 208:1108-1113.

Rice, C.W., J.H. Grove, and M.S. Smith. 1987. Estimating soil net nitrogen mineralization as affected by tillage and soil drainage due to topographic position. Can. J. Soil Sci. 67:513-520.

Ritchie, S.W., J.J. Hanway, and G.O. Benson. 1993. How a corn plant develops. Spec. Rep. 48. Iowa State Univ., Coop Ext. Service. Ames, IA.

Sanju, U.M., and B.P. Singh. 2001. Tillage, cover crop and kill-planting date effects on corn yield and soil nitrogen. Agron. J. 93:878-886.

SAS Institute. 2003. The SAS system for windows. Release 9.1. SAS Inst., Cary, NC.

Thomas, G.W. 1982. Exchangeable cations. p. 159-165. In A.L. Page et al. (ed.) Methods of soil analysis. Part 2. 2nd ed. Agron. Monogr. 9. ASA and SSSA, Madison, WI.

Varco, J.J., W.W. Frye, M.S. Smith, and C.T. MacKown. 1993. Tillage effects on legume decomposition and transformation of legume and fertilizer nitrogen-15. Soil Sci. Soc. Am. J. 57:750-756.

Webb, J.R., A.P. Mallarino, and A.M. Blackmer. 1992. Effects of residual and annually applied phosphorus on soil test values and yields of corn and soybeans. J. Prod. Agric. 5:148-152.

Woods, L.E., and G.E. Schuman. 1988. Cultivation and slope position effects on soil organic matter. Soil Sci. Soc. Am. J. 52:1371-1376.

Yoong, K.S., G.W. Clayton, and W.A. Rice. 2001. Tillage and previous crop effects on dynamics of nitrogen in a wheat-soil system. Agron. J. 93:842-849. 